International Review of Research in Open and Distributed Learning Volume 18, Number 5

August - 2017

\title{
Student and Faculty Perceptions of OpenStax in High Enrollment Courses
}

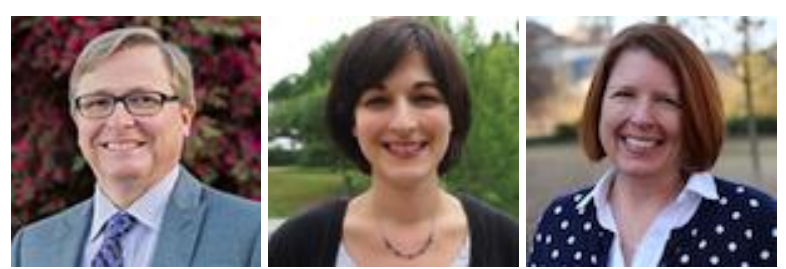

C. Edward Watson ${ }^{1}$, Denise P. Domizi ${ }^{2}$, and Sherry A. Clouser ${ }^{3}$

${ }^{1}$ Association of American Colleges and Universities, 2 University System of Georgia, ${ }^{3}$ University of Georgia

\begin{abstract}
As public funding for higher education decreases and the cost to students to attend college increases, universities are searching for strategies that save students money while also increasing their chances for success. Using free online textbooks is one such strategy, and the OpenStax College initiative at Rice University is one of the most widely recognized producers of such materials. Through a mixed method approach, this article examines the student and faculty experiences of adopting and using an OpenStax textbook. With 1,299 student participants, it was found that students greatly value the quality, attributes, and the cost of the OpenStax Biology textbook, though minor concerns were raised about its online format. Faculty adoption of a free textbook provides unique opportunities for course redesign and improvement, and the approach employed in this course transformation context resulted in clearly articulated learning outcomes, a fully realized structure in the course's learning management system, and improvements to instructional practice. The student, faculty, and course benefits of this study offer a compelling argument for the adoption of high quality open education resources (OER) in public higher education contexts.
\end{abstract}

Keywords: open educational resources, OpenStax, biology, faculty development, course design 


\section{Introduction}

As public higher education experiences significant decreases in state supported funding, the costs associated with attending college are increasing, and as a result, so is student loan debt (CBS MoneyWatch, 2012; Schoen, 2015). Textbooks are a key contributor to the overall cost of higher education, with students at four-year public institutions paying approximately $\$ 1,200$ for books and supplies each year (College Board, 2015; Wiley, Green \& Soares, 2012). Although student success is directly impacted by availability of required learning materials (Buczynski, 2007), when those materials are not affordable, students may choose not purchase them (Feldstein et al., 2012; Hilton and Laman, 2012).

At the University of Georgia, students have reported financial stresses, and that has been connected to success rates:

Despite the availability of myriad funding opportunities (both merit- and need-based), more than one-third of all UGA students who responded to the NSSE in 2011 (42\% of freshmen and 35\% of seniors) indicated that "after all financial aid is taken into consideration, [they] still have unmet financial need that makes pursuing a degree difficult.” Students receiving Federal Pell Grants and subsidized Federal Direct Loans have a lower graduation rate (8 percent lower) than students who are not receiving Federal Pell Grants or Federal Direct Student Loans (based on the 2005 Cohort of first-time, full-time freshmen) (University System of Georgia, 2013, p. 280).

In an effort to increase retention rates and reduce attrition rates at public institutions across the state, the University System of Georgia (USG) launched its Complete College Georgia initiative in 2012. The University of Georgia (UGA)-the flagship institution of the USG-has developed a number of strategies for facilitating student success. One of these is exploring the use of open educational resources (OER) in place of expensive textbooks.

OER can be defined as "teaching, learning and research resources that reside in the public domain or have been released under an intellectual property license that permits their free use or re-purposing by others" (Atkins, Brown, \& Hammond, 2007, p. 4). Examples include textbooks, research papers, simulations, and entire courses. The use of OER has been shown to save students money (UMass Amherst Libraries, 2013; Bliss, Robinson, Hilton, \& Wiley, 2012). A compelling example is the associate's degree in business administration at Tidewater Community College in Virginia in which all textbooks used by the instructors are open and free. This is reported to cut the cost of the degree in this community college context by onethird (Hulette, 2013).

As faculty consider adopting OER, quality is often a key concern (Baker, Thierstein, Fletcher, Kaur, \& Emmons, 2009). Baker and colleagues found that faculty and students have high expectations for OER, expect OER to be customizable, and prefer OER to be linked directly from the learning management system. A study of open textbook adoption at eight community colleges across the United States showed that "the majority of teachers and students perceived the OER textbooks as being of at least equal quality compared to the traditional textbooks they had used in the past" (Bliss et al., 2013, p. 14), and one third of teachers and students found them to be better than traditional texts (p. 15). Another study found that desire for "quality" included ease of use and reliability of the materials (Brent, Gibbs, \& Gruszczynska, 
2012). Faculty want to be able to find materials quickly and easily, and they expect the materials they choose to fit their teaching styles. Faculty are not only concerned with the quality of the materials, but also how their use of OER would impact the perceived quality of their own work and teaching. "Academics felt that there was an expectation that in research-led institutions especially, teachers should use examples from their own research and that course materials should be 'owned' in some sense by the person teaching the course" (Brent et al., 2012, p. 7).

Understanding the experiences of faculty members who have actually used OER could alleviate these concerns and help interested or curious faculty members make informed decisions regarding the quality of OER.

Past studies reveal a number of benefits, beyond cost savings, when OER are implemented. Faculty may find online open textbooks to be more accessible for students, particularly for searching and note-taking (Feldstein et al., 2012). Also, adoption of OER can provide opportunities for thoughtful course re-design (e.g., Fink, 2003). In particular, faculty with online or hybrid teaching experience were likely to provide their students with links to specific pages of content rather than just announcing reading assignments (Petrides Jimes, Middleton-Detzner, Walling, \& Weiss, 2011). However, as OER remain a mystery to many faculty members, and because the research on OER use is still in its early stages, exploration of the perceived benefits and challenges of adopting OER is a valuable contribution to the research.

\section{The University of Georgia (UGA) Approach}

Given the financial needs of UGA students, the goals of Complete College Georgia, and the promise of OER to save students money, the Center for Teaching and Learning (CTL) at UGA began an initiative targeting high-enrollment courses currently using expensive textbooks. By pursuing these types of courses, the collective financial impact on students at the university would be the greatest. In 2013, the CTL applied for and received a \$25,000 Incubator Grant from the USG to support this approach. The entirety of the funding went to hire a doctoral-level graduate assistant to provide instructional design and technology assistance for faculty interested in adopting an open textbook in a large-enrollment course. Three biology faculty who teach introductory biology courses to non-majors at UGA were selected to receive this graduate assistant as well as copious support from members of the CTL.

OpenStax College at Rice University is a non-profit organization that has been funded through a number of foundations, including the William and Flora Hewlett Foundation, the Laura and John Arnold Foundation, and the Bill and Melinda Gates Foundation, to produce free, open, high quality textbooks in a number of disciplines. OpenStax books are peer-reviewed, customizable, and licensed under a Creative Commons License 4.0 International. Students can access the text from OpenStax in a number of ways; they can view it online, download it to a local device, print it, or order a low-cost print version of the text (OpenStax, 2015). The biology faculty reviewed the OpenStax Biology textbook and chose to adopt it for their courses. The USG-funded graduate assistant collaborated with the faculty to nest links to specific readings within the university's learning management system and perform other tasks in support of course redesign activities required due to the switch from their existing textbook to OpenStax Biology.

\section{Assessment of the UGA Approach}


Implementing a mixed methods study, the CTL examined the resources required to adopt an open textbook, and explored faculty and student perceptions of using OpenStax. From the student perspective, we investigated financial needs, access to technology, typical use of textbooks, use of OpenStax in the course of interest, and perceived quality of the OER. We were also interested in faculty perceptions of the OER compared to other textbooks, course design considerations based on implementing OER, and faculty perceptions of how students used the OER.

\section{Method}

In fall 2013, the instructors of two large-enrollment, non-major biology courses at the University of Georgia transitioned from a traditional, printed textbook to a free and open online textbook offered by OpenStax. Students enrolled in a total of seven sections were invited to complete a survey during the last three weeks of fall 2013 and spring 2014 semesters. The survey was designed to determine students' financial needs, their access to technology, how they used both traditional and the open-textbook, and their perceived quality of the textbook.

\section{Participants}

Participants were 1,299 undergraduate students enrolled in BIOL 1103 and BIOL 1104 during fall 2013 and spring 2014. Female students comprised 69\% $(n=867)$ of the participants. Of these students, $61 \%$ $(n=756)$ had completed less than two semesters of college, 19\% $(n=235)$ had completed 3-4 semesters, and $20 \%(n=265)$ had completed five or more semesters. Students ranged in age from 18 to 36 years (see Table 1), $(\mathrm{M}=19.45, \mathrm{SD}=1.79)$.

Table 1

Participating Students, by Major

\begin{tabular}{lll}
\hline College & Response & $\%$ \\
\hline Arts and Sciences & 641 & 51 \\
Business & 191 & 15 \\
Education & 90 & 7 \\
Engineering & 103 & 8 \\
Family and Consumer Science & 72 & 6 \\
Journalism and Mass Communication & 64 & 5 \\
Other & 96 & 7
\end{tabular}

\section{Materials}

The survey consisted of 38 questions, including multiple-choice (several of which included the option of a free-text response), yes/no questions, and open-ended questions (see Appendix A for complete survey). To develop the instrument, we began by searching the literature for existing surveys in the areas of both OER and eTextbooks. Our main areas of interest were about student financial needs, student access to technology, typical use of textbooks, use of the OER in the course of interest, and perceived quality of the OpenStax Biology textbook. While the authors, in cooperation with the instructors, wrote most of the 
survey questions based on those areas of interest, the survey was informed by the literature, and several questions were used or modified from existing instruments (Bliss et al., 2013; Elias, Phillips, \& Luechtefeld, 2012; Siebenbrunner, 2011).

\section{Procedure}

During the last three weeks of fall 2013 and spring 2014 semesters, students over the age of 18 who were enrolled in BIOL 1103 and BIOL 1104 were invited to take an online survey to better understand their experience using the free textbook in this class. The students received extra credit points for completing the survey. Over the course of two semesters, 1300 students answered some or all of the survey questions with an overall response rate of 79.5\% (see Table 2 for complete breakdown).

Table 2

Student Response Rate for Online Survey

\begin{tabular}{lllllll} 
& Fall 2013 & \multicolumn{5}{c}{ Spring 2014 } \\
\cline { 1 - 5 } Enrollment & Responses & Rate & Enrollment & Responses & Rate \\
\cline { 1 - 4 } & 482 & $79 \%$ & 553 & 422 & $76 \%$ \\
279 & 217 & $78 \%$ & 196 & 179 & $91 \%$ & \multirow{2}{*}{$\begin{array}{l}\text { The open- } \\
\text { ended }\end{array}$}
\end{tabular}

questions were analyzed using HyperResearch, a qualitative data analysis software tool. For each text response given, we assigned a code that represented the content of that response. For example, the first open-ended question was, "What did you like the most about the OpenStax textbook?" Responses such as, "It was free," "I did not have to buy the book," and "no cost" were each assigned the code, "free." After coding approximately one hundred of the responses and either assigning previously assigned codes or creating new codes as needed, we were able to auto-code the rest of the responses using the key words we had identified from the sample coding.

\section{Results}

\section{Student Financial Considerations}

Forty-nine percent of the students surveyed reported that they received loans to pay for some (42\%) or all (7\%) of their education. Almost half of the students (49\%) indicated that they spend over \$300 per semester on books (see Table 3). Realizing that $61 \%$ of these were first-year students, and that they all had at least one free textbook that semester (i.e., the OpenStax Biology textbook), these amounts are probably lower than for the general student population. When asked if they had difficulty coming up with the money to pay for their textbooks, $42 \%$ agreed or strongly agreed with that statement.

Table 3 
Students' Response to Question, “How Much do you Typically Spend on Textbooks Each Semester?”

\begin{tabular}{lll} 
Answer & Response & $\%$ \\
\hline Less than \$100 & 27 & $2 \%$ \\
$\$ 101-\$ 200$ & 209 & $17 \%$ \\
$\$ 201-\$ 300$ & 398 & $32 \%$ \\
$\$ 301-\$ 400$ & 358 & $29 \%$ \\
$\$ 401-\$ 500$ & 187 & $15 \%$ \\
More than \$500 & 64 & $5 \%$ \\
Total & 1,243 & $100 \%$
\end{tabular}

\section{Student Textbook Use}

When asked how often they bought the required textbooks for their courses, 29\% of the students reported that they always bought the book, and 47\% said they bought the book most of the time. For those who did not always buy the book (71\%), we asked, "If you have ever made the decision not to buy the required textbook, what has influenced that decision? Check all that apply." Their answers are represented in Table 4 .

Table 4

Students' Response to Question, "If You Have Ever Made the Decision Not to Buy the Required Textbook, What Has Influenced That Decision? Check All That Apply."

\begin{tabular}{lcc} 
Answer & Response & $\%$ \\
\hline Too expensive & 656 & 57 \\
I rarely use them & 675 & 59 \\
$\begin{array}{l}\text { They are unnecessary to successfully } \\
\text { pass the class }\end{array}$ & 656 & 57 \\
I borrowed or shared the textbook & 499 & 44 \\
Other & 67 & 6
\end{tabular}

Because the students could access the OpenStax textbook electronically or by printing the readings, we were interested in how the students accessed and interacted with the OpenStax textbook. Eighty-eight percent responded that it was easy for them to access electronic materials; 92\% said that they could access electronic materials most or all of the time. Fifty-two percent preferred to read printed hard copies, $18 \%$ preferred to read electronically (i.e., computer, tablet, phone, eReader), and 29\% had no preference. This was somewhat at 
odds with their response to the question, "How do you prefer to access the free BIOL OpenStax textbook for this class?" In response to that question, only $5 \%$ indicated that they printed the material; the rest said they accessed it electronically through the links on the learning management system (69\%), PDFs downloaded to their computers (19\%), or through the OpenStax website (7\%). It is possible that the question of access was phrased in such a way that it was not clear to the students or that the students were choosing not to print the text even though that was their preferred method of reading.

\section{Student Overall Impressions of OER}

Sixty-percent of the students reported that they told someone that they were using a free textbook in their biology class. People they told included parents or guardians (71\%), friends (71\%), roommates (61\%), siblings (20\%), classmates in other classes (46\%), and instructors of other courses (6\%).

We were also interested in students' overall impressions of the OpenStax textbook. Students were asked to rate the quality of the OpenStax textbook as compared to other textbooks they had used. Sixty-four percent said the quality was about the same, and 22\% said it was higher or much higher than other textbooks. With regards to the readability of the OpenStax textbook, 64\% of the students said it was "good" or "very good," 31\% said it was "fair," and 5\% said it was "poor" or "very poor."

In an open-ended question, we asked students what they liked best about the OpenStax book. For the most part, their responses were brief and they listed one or two things. For example, "It is easy to access and free" is a representative response to this question. The most common response was that they liked that it was free $(n=604)$. Students also indicated it was easy to access the text $(n=265)$, with comments such as, "I can access it from my computer, so that I don't have to always bring it with me." There were also comments about the nature of the format. For example, students said they liked that, "our professor can link [to] specific chapters we need to read on the checklist;" and that "I can use word search on my computer to find something specific very fast."

When asked what they liked the least about the OpenStax textbook, again most students gave brief responses with one or two points in their answers. One student, however, gave a more lengthy response. Interestingly, this response is representative of the range of frequently cited "least favorite" aspects of the text, with a particular emphasis on the first two points:

My first would be that I cannot physically highlight and make notes directly on the page, which is how I effectively study (especially through direct notes). The fact that I must make notes separately also divides my attention between two texts. My second is that it occasionally hurts/strains my eyes to stare at a screen all the time (I am an extremely meticulous/sometimes slow reader). My third is that having my study material on a laptop constantly distracts my attention. My fourth, and least applicable, is that I just prefer the feel of a tangible textbook; I have found my focus, comprehension, and overall picturing of the material to be better when I physically turn the pages and look through what I've read.

As represented by this student, the most common complaints had to do with limitations of interacting with an online or electronic text in terms of highlighting and annotating, and the eyestrain that can 
accompany long periods of time online. Finally, some students asserted that there were assigned readings that were "irrelevant to what we need to know" and that were "not completely related to what is being taught in class."

Students were also asked, "What ideas do you have regarding how the BIOL OpenStax textbook could be used or integrated differently in the course?" The most frequent response had to do with better reading/lecture/assessment integration. Typical responses included, "the course would have been better if the lecture coincided with what was read in the textbook," and "have the material integrated into the test so students are more encouraged to read the material, and give more incentives for students that take the time to read the material."

Another frequent response concerned the amount of reading. Students recommended more specific and targeted reading assignments: "Reading should be more concise. Some of the stuff we read in the text never really applies to what we learn in class."

\section{Faculty Considerations}

Toward the end of the fall 2013 semester, a focus group interview was conducted with three faculty members who were teaching BIOL 1103 and 1104 with the OpenStax textbook for the first time that semester. The following themes emerged from this conversation.

Comparison to other textbooks. When comparing the quality of the OpenStax textbook to other printed textbooks they had previously used, the faculty participants agreed that there were things that were missing from the OpenStax textbook, but that they "always had the same experience with regular textbooks, too." They discussed modifications they made to address these issues, such as finding figures online, and animations that were "better representations of what's happening."

The faculty participants also felt that there were fewer supplemental materials provided with the OpenStax textbook. For example, while there were end-of-chapter questions and a glossary of terms, there was no test bank, and no PowerPoint presentations provided. They agreed that it might be more difficult to teach with the OpenStax textbook if they had not already had a test bank of questions from previous semesters teaching the class. One remarked that the PowerPoint presentations provided by publishers are usually "really terrible" and so they were not missed.

They also talked about how they modified the reading. They found it complicated to edit the chapters, so typically they would either select very specific sections of a chapter to assign to students, or "cut and paste [certain sections] and just say, 'this is your reading'... Then watch a couple animations and some guiding questions as you're watching them."

Modifications to information organization. The faculty participants used the new text as an opportunity to rethink how they organized the content for their students.

Rather than just kind of having it be on a syllabus and sort of making things available in one document, I thought, why don't we make things more electronically accessible since the book is electronically accessible. So I hadn't [given them] objectives for reading before because its like, 
where are you gonna put them? It's too big on the syllabus and you can give it to them in class but they're not really paying attention, and you can put links up to animations that you wanted them to watch before class it's like, how do you kind of get all that content in manageable pieces? So I think the changes related to reimagining how you could organize the delivery of information to students like using checklists [in the learning management system].

Students could now go to one place to access a checklist with all of their assignments for that week, including objectives and links to the reading, animations, figures, and quizzes.

Perceptions of student use of textbook. Most of the students enrolled in the BIOL 1103 and 1104 courses were in their first (61\%) or second (19\%) year of college, coming from a high school background where books were free. The faculty participants agreed that they felt that their students did not "put a lot of value in a textbook," and expressed surprise when students questioned the amount of reading:

One student said, 'I mean are we supposed to read all this? The assignments seem like we're supposed to read a lot of pages.' I clicked on the link for the day and it was like a page and a half, like, that's really not that much.

Added another faculty participant,

We would put like three links up and one might be a little two-minute animation and then one might be like, a page and a half of reading... but I think if you look at it, you think, 'oh my god there's like five things I have to do.'

Departmental considerations. While all of the faculty participants agreed that they would continue to use the OpenStax textbook in the future, they did mention challenges within departments due to perceptions and expectations of other faculty members. Some colleagues in the department had expressed concern to our faculty participants that students would "miss out on a bunch of stuff" if changes were made to the curriculum. Others were thinking about time constraints: "We have instructors that would not touch this, right, so they were like, 'I don't want to change anything, I got it set, I just want to do it this way, it's a lot of work.” On the other hand, one faculty participant commented,

I think it depends on how you built your course, too. If you built your course around a textbook, switching is hard, but if you built your course and then you fit in the textbook as a resource, it's not that hard.

Another concern our faculty participants had heard was with regards to keeping the textbook current and updated:

Faculty have come to me and said, 'how do you know this is gonna be updated, how are they gonna keep it updated?' and I was like, “...have you looked at some of these textbooks? I mean, I know they update on a regular three year cycle but it's just so that they can continue, you know, to charge new book prices. Not that much changed. 


\section{Discussion}

Unsurprisingly, students were exceptionally pleased with the savings offered by the OpenStax textbook. Regarding quality, faculty and student perceptions alike perceived the content available in OpenStax Biology to be comparable to similar textbooks produced by traditional publishers; however, students recognized additional benefits to the OER textbook, including its search-ability, portability, and the professor's capability to deep link to specific passages from the course's larger organization structure as developed within the institution's learning management system. Alternatively, a minority of students lamented the loss of functionality found with traditional textbooks, including the ability to write notes in the margins. Some students also voiced concerns over eyestrain and distractions caused by being online to engage with the textbook. Students had the ability to purchase a print copy of the text or to print passages themselves; however, it's likely that many students chose not to do so due to the inherent perceived costs of those activities, however minor as compared to traditionally published textbooks.

Faculty found the flexibility of the OpenStax textbook very useful. Their ability to link directly to content they planned to use and to add additional content using the learning management system contributed to their overall level of satisfaction with the content and associated tools. Faculty adopters in this study noted concern from colleagues who were unfamiliar with notions of open education resources generally, and OpenStax specifically, and those faculty sometimes found themselves defending their choices in these contexts; however, their ability to describe their firsthand experiences with the quality of traditional and online textbooks, coupled with cost comparisons, made those concerns and discussions easier to navigate.

From the perspective of teaching and learning centres that often play a key institutional role in the adoption of OER, transitions from one textbook to another provide opportunities to assist faculty with broader course improvement activities. As a part of our process, we facilitated the crafting of learning outcomes for each module throughout the course that aligned with the readings and other course activities for that week. These activities fostered opportunities to offer recommendations for course-level instruction and assessment beyond the readings for the course. As a result, the adoption of the OER textbook led to significant course redesign.

\section{Conclusion}

Though faculty and students identified both positive and negative aspects in the free online format, they found the quality of the OpenStax content to be comparable to that found in traditional textbooks. Ultimately, however, the adoption of the free online textbooks ensures that all students, regardless of their socio-economic background or financial challenges, have access to the required course materials on the first day of class. As institutions consider how to improve various student success metrics, the adoption of free, open textbooks helps to level the educational playing field for all students. Additionally, when multiple courses implement high-quality free textbooks, there is the potential to create significant cost savings that can lower financial hurdles for students matriculating toward graduation. Such student 
benefits, coupled with opportunities for course revision and improvement, create a compelling argument for the broad adoption of OER at public institutions of higher learning.

\section{References}

Atkins, D. E., Brown, J. S., \& Hammond, A. L. (2007). A review of the open educational resources (OER) movement: Achievements, challenges, and new opportunities. Retrieved from The William and Flora Hewlett Foundation website: http://www.hewlett.org/uploads/files/ReviewoftheOERMovement.pdf

Baker, J., Thierstein, J., Fletcher, K., Kaur, M., \& Emmons, J. (2009). Open textbook proof-of-concept via Connexions. The International Review of Research in Open and Distance Learning, 10(5), 1-13.

Bliss, T., Robinson, T. J., Hilton, J., \& Wiley, D. A. (2013). An OER COUP: College teacher and student perceptions of Open Educational Resources. Journal of Interactive Media in Education, (1)4. Retrieved from http://jime.open.ac.uk/article/view/252. doi:10.5334/2013-04

Brent, I., Gibbs, G., \& Gruszczynska, A. (2012). Obstacles to creating and finding open educational resources: The case of research methods in the social sciences. Journal of Interactive Media in Education, (1)5. Retrieved from http://jime.open.ac.uk/article/view/2012-05/428. doi:10.5334/2012-05

Buczynski, J. (2007). Faculty begin to replace textbooks with "freely" accessible online resources. Internet Reference Services Quarterly, 11(4), 169-179. Retrieved from http://dx.doi.org/10.1300/J136v11no4 11

CBS MoneyWatch. (2012, September 21). Why college tuition keeps rising. Retrieved from http://www.cbsnews.com/8301-505145_162-57517032/why-college-tuition-keeps-rising/

College Board. (2015). Quick guide: College costs. Retrieved from https://bigfuture.collegeboard.org/payfor-college/college-costs/quick-guide-college-costs

Elias, E. C., Phillips, D. C., \& Luechtefeld, M. E. (2012). E-books in the classroom: A survey of students and faculty at a school of pharmacy. Currents in Pharmacy Teaching and Learning, 4(4). doi:10.1016/j.cptl.2012.05.009

Feldstein, A., Martin, M., Hudson, A., Warren, K., Hilton, J., \& Wiley, D. (2012). Open textbooks and increase student access and outcomes. European Journal of Open, Distance, and E-learning, 2. Retrieved from http://files.eric.ed.gov/fulltext/EJ992490.pdf 
Fink, L.D. (2003). Creating significant learning experiences: An integrated approach to designing college courses. San Francisco, CA: John Wiley \& Sons, Inc.

Hilton, J., \& Laman, C. (2012). One college's use of an open psychology textbook. Open Learning: The Journal of Open, Distance and E-Learning, 27(3), 265-272. doi:10.1080/02680513.2012.716657

Hulette, E. (2013, March 15). TCC plans to offer degree, textbooks not required. Retrieved from http://hamptonroads.com/2013/03/tcc-plans-offer-degree-textbooksnot-required

OpenStax. (2015). OpenStax College: Free your students from costly textbooks. Retrieved from https://openstaxcollege.org/faculty

Petrides, L., Jimes, C., Middleton-Detzner, C., Walling, J., \& Weiss, S. (2011). Open textbook adoption and use: Implications for teachers and learnings. Open Learning, 26(1), 39-49. doi:10:1080/02680513.2011.538563

Schoen, J. W. (2015, June 16). Why does a college degree cost so much? Retrieved from http://www.cnbc.com/2015/06/16/why-college-costs-are-so-high-and-rising.html

Siebenbrunner, J. (2011). Electronic versus Traditional Textbooks: A Comparison of College Textbook Formats. Retrieved from http://eric.ed.gov/?id=EJ951836

UMass Amherst Libraries (2013, February 19). The open education initiative @ UMass Amherst. Retrieved from http://guides.library.umass.edu/content.php?pid=87648\&sid=1714807

University System of Georgia (2013, October). Complete College Georgia: Updates on campus completion plans. Retrieved from http://www.usg.edu/educational access/documents/University-Systemof-Georgia-Campus-Completion-Plan-Updates-October-2013.pdf

Wiley, D., Green, C., \& Soares, L. (2012). Dramatically bringing down the cost of education with OER. How open education resources unlock the door to free learning. Center for American Progress. Retrieved from http://www.americanprogress.org/wpcontent/uploads/issues/2012/o2/pdf/open_education_resources.pdf 


\section{Appendix A}

\section{OER Survey}

Dear student,

We are researchers from the Center for Teaching and Learning at The University of Georgia. We invite you to participate in a research study entitled, Investigating the use of open educational resources in the college classroom, that is being conducted under the auspices of the University System of Georgia. The purpose of this study is to better understand your experience using the free textbook in this class.

Your participation will involve completing this online survey and should only take about 10-15 minutes. Your involvement in the study is voluntary, and you may choose not to participate or to stop at any time without penalty or loss of benefits to which you are otherwise entitled. Your decision about participation will have no bearing on your grades or class standing. If you decide to stop or withdraw from the study, the information/data collected from or about you up to the point of your withdrawal will be kept as part of the study and may continue to be analyzed. Existing data from midterm evaluations will also be used; that data has no identifying information.

All of your responses will remain confidential; your instructor will know that you completed the survey, but will not be able to associate your name with your responses, and your responses will not be associated with your name in any way. With the Internet, your confidentiality will be maintained to the degree permitted by the technology used. Specifically, no guarantees can be made regarding the interception of data sent via the Internet by any third parties. The results of the research study may be published, but because there is no way to associate your particular responses to you, your name or any identifying information will not be used.

The findings from this project may provide information on the adoption and use of Open Educational Resources. There are no known risks or discomforts associated with this research.

If you have any questions about this research project, please feel free to call me Denise Domizi at the Center for Teaching and Learning at (706) XXX-XXXX or send an e-mail to XXX@uga.edu. Questions or concerns about your rights as a research participant should be directed to The Chairperson, University of Georgia Institutional Review Board, 629 Boyd GSRC, Athens, Georgia 30602; telephone (706) XXXXXXX; email address irb@uga.edu.

By completing the following online survey, you are agreeing to participate in the above described research project. Thank you for your consideration! You may print this page for your records before proceeding to the survey.

Sincerely, Denise Pinette Domizi, Ph.D.

C. Edward Watson, Ph.D. 
I agree to participate in this research study. (1)

Please enter your name. (Your name will not be linked with your responses; your professor will not know how you answered any of the questions).

Last (1)

First (2)

Please enter your \#810 (student ID number) with no spaces. Your 810 number will not be linked with your responses; your professor will not know how you answered any of the questions.

$810 \ldots(1)$

What is your age?

What is your gender?

O Male (1)

O Female (2)

O Prefer not to answer (3)

School/College

O Agricultural and Environmental Sciences (1)

O Arts in Franklin College (2)

O Business (3)

O Ecology (4)

O Education (5)

O Engineering (6)

O Environment and Design (7)

O Family and Consumer Sciences (8)

O Forestry and Natural Resources (9)

O Journalism and Mass Communication (10)

O Law (11)

O Pharmacy (12)

O Public Health (13)

O Public and International Affairs (14)

O Sciences in Franklin College (15)

O Social Work (16)

O Veterinary Medicine (17)

How much do you agree with the following statement: It is easy for me to access electronic material.

O Strongly Disagree (1)

O Disagree (2)

O Neutral (3)

O Agree (4)

O Strongly Agree (5) 
How often are you able to access electronic materials?

O Never (1)

O Rarely (2)

O Sometimes (3)

O Most of the time (4)

O Always (5)

On average, how many hours per day do you use a computer or tablet?
O $0-3(1)$
O $4-6(2)$
O $7-9(3)$
O $10-12(4)$
O $12-15(5)$
O $16+(6)$

How many semesters have you completed in college?

O Less than 1 (1)

O 1-2 (2)

O $3-4(3)$

O $5-6(4)$

O $7-8(5)$

O 9-10 (6)

O More than $10(7)$

Have you received any loans to fund your education?

O Loans are funding all of my education (1)

O Loans are funding some of my education (2)

O I am not using loans to fund my education. (3)

To what extent do you agree with this statement: I have difficulty coming up with the money to pay for my textbooks.

O Strongly Disagree (1)

O Disagree (2)

O Neutral (3)

O Agree (4)

O Strongly Agree (5)

Instructions: Please answer the following questions with regards to your general use of textbooks across all of your classes since coming to UGA. If this is your first semester, answer these questions with regards to this semester.

In general, how often do you purchase the required textbooks for the courses you take?
O Never (1)
O Rarely (2)
O Sometimes (3)
O Most of the time (4)
O Always (5) 
How much do you typically spend on textbooks each semester?

Less than $\$ 100(1)$

O $\$ 101$ 1- $\$ 200(2)$

○ $\$ 201-\$ 300(3)$

O $\$ 301-\$ 400(4)$

O $\$ 401-\$ 500(5)$

O More than $\$ 500(6)$

If you have ever made the decision not to buy the required textbook, what has influenced that decision? Check all that apply.

ㄱoo expensive (1)

I rarely use them (2)

They are unnecessary to successfully pass the class (3)

I I borrowed or shared the textbook (4)

$\square$ Other (5)

For a typical course, how often do you use the required texts?

O Never (1)

O 2-3 Times a Semester (2)

O 2-3 Times a Month (3)

O 2-3 Times a Week (4)

O Daily (5)

For a typical course, do you primarily:

O Read most of the text (1)

O Skim the text (2)

O Usually do not read the text (3)

If the textbooks used in your classes were available electronically, would you be more likely to take your textbooks to class?

O Strongly disagree (1)

O Disagree (2)

O Neutral (3)

O Agree (4)

O Strongly agree (5)

Do you prefer reading textbooks electronically or through printed hard copies?

O Electronically (i.e. computer, tablet, phone, eReader) (1)

O Printed hard copies (2)

O No preference (3)

How often do you read books of any kind electronically?

O Never (1)

O Rarely (2)

O Sometimes (3)

O Most of the time (4)

O Always (5) 


\section{Instructions: Please answer the following questions with regards to the free OpenStax textbook used in BIOL.}

Did you tell anyone that you were using a free textbook in BIOL this semester?

O Yes (1)

O No (2)

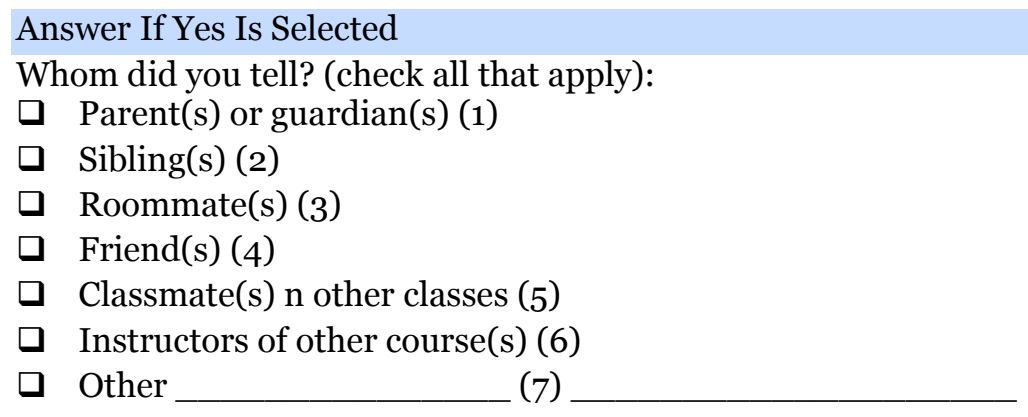

How do you prefer to access the free BIOL OpenStax textbook for this class?

O Through the OpenStax website on my laptop, desktop, phone, or tablet computer (1)

O Through the section links on the checklists in eLC-New. (2)

O PDFs downloaded to my computer, tablet, or eReader (3)

O I print the material (4)

How do you interact with the OpenStax text?

O I read, make notes, and/or highlight on the printed paper (1)

O I read, make notes, and/or highlight on the electronic version (2)

I make notes in a separate electronic document (for example, Microsoft Word, Google docs) (3)

O I read the text and try to remember what I am reading (4)

O Other (5)

How often have you used the OpenStax textbook for this course during the semester?

O Never (1)

O 2-3 Times a Semester (2)

O 2-3 Times a Month (3)

O 2-3 Times a Week (4)

O Daily (5)

For this course's OpenStax textbook, which do you do primarily:

O Read the text word for word (1)

O Skim the text (2)

O Usually do not read the text (3)

How often, if at all, do you have trouble accessing the OpenStax website?

O Never (1)

O 2-3 Times a Semester (2)

O 2-3 Times a Month (3)

O 2-3 Times a Week (4)

O Daily (5)

What is your favorite thing about the OpenStax textbook? 
What is your least favorite thing about the OpenStax textbook?

\section{Instructions: Please answer the following questions with regards to the quality and usability of the free OpenStax textbook used in BIOL.}

How would you rate the readability of the BIOL OpenStax textbook?

O Very poor (1)

O Poor (2)

O Fair (3)

O Good (4)

O Very good (5)

How important were the OpenStax textbook readings to your academic performance in BIOL?

O Not important (1)

O Somewhat important (2)

O Very important (3)

O Essential (4)

How would you rate the quality of the BIOL OpenStax textbook as compared to other textbooks you have used used?

O Much lower (1)

Slightly lower (2)

O About the same (3)

O Higher (4)

O Much higher (5)

How likely are you to register for a future course that uses a free textbook like the OpenStax textbook used in this course?

O No chance (1)

O Very little chance (2)

O Some chance (3)

O Very good chance (4)

Imagine a future course you are required to take. If the same instructor offers two different sections of this course during equally desirable time slots, but one section uses free digital textbooks and the other uses traditional published textbooks, which section would you prefer to enroll in?

O I would enroll in the section that uses a TRADITIONAL PUBLISHED (1)

O TEXTBOOK (2)

O I would enroll in the section that uses a FREE DIGITAL TEXTBOOK (3)

I would have no preference (4)

What ideas do you have regarding how the BIOL OpenStax textbook could be used or integrated differently in the course?

Is there anything else you would like to say about the OpenStax textbook used in this class?

\section{Athabasca University}

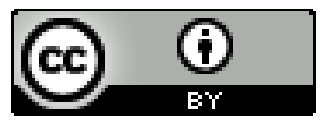

